or consist of, cistrons then fractionation of the gene can occur, which will reduce the original genic effect. This principle is of wide importance in human genetics. In Eskimo $X$ Nordic ${ }^{6}$, the $F_{1} X$ Nordic can produce an individual having blue eyes, fair hair and white skin like the original grandfather. Thus the gene for blue eyes, for example, segxegates as a complete unit in this racial cross. But in the European population many intergrades between blue and brown iris occur which have never been properly studied but which may be reasonably attributed to fractionation of the original gene.

As regards the blood groups, it is evident that $A B O$ are original or ancestral genes, and that $A_{1}, A_{2}$, otc., are later developments produced by fractioning of the original gene so that its effect is milder in different degrees. Similarly, there is evidence that brachycephaly first appeared in the Upper Palæolithic as a marked departure from the previous dolichocephaly. Later, more extreme forms of brachycephaly as well as intermediate cephalic indices have probably been produced, partly by fractionation of the original gene, through hybridization or otherwise. Thus in many cases the more extreme form of a gene appears first and its lesser and later forms bridge the gap by means of a series of sub-genes.

\section{R. Ruggles Gates}

18 Concord Avenue,

Cambridge 38, Mass.

1 Champness, L. T., Kooptzoff, O., anil Walsh, R. J., Oceania (in the press).

2 Gates, R. R., Acta Genet. Med. et Gemell., 7, 159 (1958).

${ }^{3}$ Bijlmer, II. J. T., Nova Guinea, N.S., 3, 113 (1939).

${ }^{4}$ Fahmy, C. G., and Fahmy, M. J., Nature, 184, 1927 (1959).

s Benzer, S., "The Elementary Units of Heredity" in "Chemical Basis of Heredity", 70 (Johns Hopkins Press, 1956).

"Gates, R. R., "Heredity in Man", 385 (London, 1929).

\section{GEOLOGY}

\section{Geological Reconnaissance of the Sör-Rondane Mountains (Queen Maud Land)}

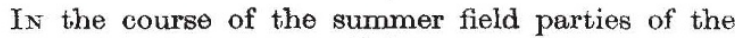
Expedition Antarctique Belge 1957-58, I carried out a geological reconnaissance in the Sör-Rondane ranges, unexplored up to then.

This massif extends over approximately $250 \mathrm{~km}$. east and west (from $23^{\circ} \mathrm{E}$. to $28^{\circ} \mathrm{E}$.) and has a depth of about $100 \mathrm{~km}$. The foot-hills of the chain lie about $150 \mathrm{~km}$. inland from the coast, at approximately $72^{\circ} \mathrm{S}$. latitude. The summits are elevated between 1,200 and $3,500 \mathrm{~m}$. above sea-level and the snow-line lies between 1,000 and $3,000 \mathrm{~m}$.

The present topographical features have resulted. from glacial erosion followed by a long stage of postglacial erosion due mainly to mechanical weathering. The highest peaks investigated show evidence of heavy glaciation.

The region investigated is formed entirely of crystalline rocks, there being no trace of non- metamorphosed sedimentary rocks, nor of pizonal metamorphism.

The nunataks to the north of the chain are formed of intrusive igneous rocks (coarse-grained red granite at Roemnesfjell, diorites at Nordtoppen and Småhausane).

The mountain chain itself is formed of migmatites and highly varied, though mainly biotitic and amphibolic, gneiss. In one occurrence (at Austkampane) the gneiss is interspersed with layers of pure erystalline limestone associated with banks of calcium silicate gneiss. Homogeneous massifs of dioritic gneiss are also found. The general direction of the gneiss is east-west; the dip is very variable.

The gneissic complex, at certain points, is transected by a disordered network of pegmatitic and granitic dykes. The intensity and widespread occurrence of this phenomenon are striking characteristies of the region.

The phenomena of anatexy and of migmatization are widespread. This gneissic eomplex obviously forms part of the eastorn Antarctic Pre-cambrian complex. The igneous intrusives to the north of the chain are clearly later than the gneiss but of unknown age.

There is no evidence of mineralization either in the gneiss or in the igneous intrusives.

The following successive stages in the geological history of this region are identifiable: (I) the deposition of a vast and varied sedimentary complex, including limestone deposits, under geosynclinal conditions ; (2) the folding and metamorphism of the sedimentary complex in a deep zone (upper catazone), accompanied by dioritic intrusions; (3) the intrusion of granitic and dioritic rocks into the gneiss; (4) the formation of granitic and pegmatie dykes cutting through the intrusive bodies.

The radioactivity dating of the samples at present being carried out will furnish more precise information as to the chronology of these stages.

I wish to thank Dr. Jacques Giot, who led the sled journey into the Sör-Rondane, and Drs. Paul and Jean Michot, who are carrying out the petrographical study of the samples collected.

The geographical names refer to the map of the Sör-Rondane Mountains, published by the Norsk Polarinstitutt, in 1957.

\section{E. F. Picciotio}

Laboratoire de Physique Nucléaire, Université Libre de Bruxelles. 